\title{
Pengolahan Zat Warna Direk Limbah Cair Industri Jumputan Menggunakan Karbon Aktif Limbah Tempurung Kelapa pada Kolom Adsorpsi
}

\author{
Processing of Direk Waste Liquid Colors from Jumputan Industry use Active \\ Carbon of Coconut Waste in Adsorption Column
}

\author{
Prahady Susmanto ${ }^{*}$, Yandriani ${ }^{2}$, Arin Putri Dila ${ }^{3}$, Dela Regina Pratiwi ${ }^{4}$ \\ 1,2,3,4) Jurusan Teknik Kimia Fakultas Teknik Universitas Sriwijaya \\ Jl. Raya Indralaya-Prabumulih KM. 32 Indralaya Ogan Ilir (OI) 30662 \\ email: ${ }^{* 1}$ prahady.susmanto@ft.unsri.ac.id, ${ }^{2}$ yandriani@ft.unsri.ac.id
}

\begin{abstract}
DOI;
Kain jumputan adalah salah satu industri tekstil yang berkembang di

10.30595/jrst.v4i2.7309

Indonesia. Dalam pembuatannya kain jumputan ini banyak menggunakan zat warna sintesis, salah satunya zat warna direk. Penggunaan zat warna

Histori Artikel: sintetis menyebabkan masalah yang serius bagi lingkungan terutama masalah yang diakibatkan oleh limbah cair yang dihasilkan karena sebagian

Diajukan:

03/05/2020 besar zat warna bersifat sukar terurai. Salah satu metode yang terbukti efektif untuk menghilangkan zat warna adalah adsorpsi menggunakan karbon aktif secara kontinyu. Pada penelitian ini karbon aktif dibuat dari

Direvisi: limbah tempurung kelapa dengan variasi aktivator HCL (0, 5, $1015 \%)$. $27 / 08 / 2020$ Hasil penelitian menunjukkan bahwa variasi konsentrasi HCL mempengaruhi mutu karbon aktif antara lain kadar air 1,30\%, kadar abu

Diterima:

$23 / 09 / 2020$ $3,04 \%$, kadar zat terbang 9,90\%, kadar karbon terikat 85,86\% dan daya serap terhadap iodin 379,51\% yang telah memenuhi SNI 06 - 3730 - 1995 tentang arang aktif teknis. Kemudian, karbon aktif tersebut digunakan untuk menyerap zat warna direk yang ada pada limbah jumputan dengan variasi waktu adsorpsi (10, 20, 3040 menit). Hasil penelitian menunjukkan bahwa karbon aktif yang teraktivasi HCL 15\% (v/v) dengan waktu 40 menit memberikan hasil penyerapan terbaik yaitu sebesar 92,8\% dengan konsentrasi zat warna sisa sebesar 8,0865 mg/L. Model kesetimbangan yang sesuai yaitu menggunakan model isotherm Langmuir dan Fruendlich.
\end{abstract}

Kata Kunci: Adsorpsi, Karbon, Limbah Jumputan, Tempurung Kelapa, Zat Warna

\begin{abstract}
Kain jumputan is one of the textile industries that is developing in Indonesia. In making this cloth, many wraps use synthetic dyes, one of which is dyes recruited. The use of dyes causes serious problems for the environment. The main problem caused by liquid waste produced by most voluntary dyes breaks down. One method that is proven effective for removing dyestuffs is adsorption using activated carbon continuously. In this study activated carbon was made from coconut shell waste with variations of HCL activators (0, 5, 10 15\%). The results showed that the variation of HCL conversion affected the activated carbon between water content $1,30 \%$, ash content $3,04 \%$, fly ash content $9,90 \%$ carbon content $85,86 \%$ and iodine absorption 379,51\% which had obtained SNI 06-3730-1995 concerning technical active charcoal. Then, this activated carbon is used to absorb the dyes present in the waste with variations in the time of adsorption $(10,20,3040$ minutes). The results showed that activated carbon activated by HCL $15 \%(\mathrm{v} / \mathrm{v}$ ) with a time of 40 minutes gave the best results of $92.8 \%$ with a dye concentration of $8.0865 \mathrm{mg} / \mathrm{L}$. The appropriate equilibrium model was using Langmuir and Fruendlich isotherm model.
\end{abstract}

Keywords: Adsorption, Carbon, Jumputan Waste, Coconut Shell, Color Substance 


\section{PENDAHULUAN}

Kain jumputan Palembang merupakan komoditi yang berkembang pesat seiring dengan banyaknya permintaan konsumen dari berbagai daerah maupun mancanegara. Dalam pembuatannya kain jumputan ini banyak menggunakan zat warna sintesis. Zat Warna sintesis dipilih karena intensitas warna yang tinggi dan sangat variatif dibandingkan pewarnaan dengan meggunakan zat warna alami. Namun, seiring dengan perkembangan industri tekstil yang demikian cepat penggunaan zat warna sintetis tersebut menimbulkan masalah yang serius bagi lingkungan terutama masalah yang diakibatkan oleh limbah cair yang dihasilkan. Industri tersebut sebagian besar merupakan industri rumahan yang umumnya belum memiliki pengolahan limbah cair yang cukup baik sehingga air limbah yang ada dibuang begitu saja ke lingkungan memberikan potensi yang sangat besar sebagai penyebab pencemaran air.

Limbah cair industri tekstil bersumber dari proses pencelupan, pencucian, pengukuran, pencetakan dan penyempurnaan (Atmaji dkk., 1999). Salah satu zat warna sintetik yang digunakan dalam proses pencelupan kain jumputan adalah direk. Zat warna direk merupakan zat warna golongan azo yang dapat dengan cepat menyerap baik pada serat selulosa. Menurut Chequer,dkk (2011) pewarna azo adalah pewarna sintesis dari pasangan amine yang terdeazotisasi menjadi senyawa organik (amine atau fenol) yang memiliki satu atau lebih gugus azo $-\mathrm{N}=\mathrm{N}$ yang berikatan dengan gugus cincin aromatik, dan dapat terlarut dalam air. Pewarna azo sebagai pewarna utama yang paling banyak digunakan pada industri tekstil dan limbah yang dihasilkan dari pewarnaan ini tergolong sulit untuk didegradasi. Meski pewarna azo dapat bersifat nontoksik pada kadar rendah bagi tubuh manusia, namun pada kadar atau jenis azo tertentu dapat bersifat toksik dan karsinogenik (Dewi \& Lestari, 2010).

Limbah cair yang dihasilkan industri tekstil umumnya memiliki konsentrasi yang cukup tinggi, tidak terkecuali industri tekstil kain jumputan yang terdapat di kota Palembang. Telah banyak penelitian yang dilakukan sebelumnya mengenai penghilangan warna dan senyawa organik yang terdapat pada limbah cair kain jumputan baik menggunakan proses biologi, kimia, maupun fisika Ada beberapa metode yang tersedia untuk menghilangkan warna dari air dan air limbah seperti pemisahan membran, degradasi aerobik dan anaerob menggunakan berbagai mikroorganisme, oksidasi kimia, koagulasi dan flokulasi, dan reverseosmosis. Beberapa teknik ini telah terbukti efektif dalam pengolahan air limbah. Akan tetapi, juga memiliki beberapa keterbatasan seperti kelebihan penggunaan bahan kimia, akumulasi lumpur terkonsentrasi yang memiliki masalah pembuangan yang serius dan kurangnya pengurangan warna yang efektif.

Teknik adsorpsi, yang didasarkan pada transfer polutan dari larutan ke fase padat, dikenal sebagai salah satu metode pengolahan air limbah yang efisien dan umum (Ghaedi dkk., 2012). Metode ini lebih unggul dari teknik penghilangan pewarna lainnya dalam hal biaya awal, kesederhanaan desain, kemudahan operasi, dan non-toksisitas dari adsorben yang digunakan dibandingkan dengan metode pengolahan limbah konvensional lainnya (Kismir dan Aroguz, 2011). Selain itu, penerapan prosedur adsorpsi terutama berdasarkan pada adsorben yang non-toksik dan ramah lingkungan dan atom permukaan yang reaktif dari adsorben sangat diminati (Chiou dan Chuang, 2006).

Adsorpsi pada karbon aktif lebih unggul dibandingkan dengan metode kimia dan fisika lainnya untuk pengolahan air limbah dalam hal kemampuannya untuk menyerap berbagai polutan secara efisien, kinetika adsorpsi cepat dan kesederhanaan desainnya. Namun, karbon aktif yang tersedia secara komersial masih mahal karena penggunaan bahan awal yang tidak terbarukan dan relatif mahal seperti batubara, yang tidak dibenarkan dalam aplikasi pengendalian polusi. Oleh karena itu, dalam beberapa tahun terakhir, banyak peneliti telah mencoba untuk memproduksi karbon aktif untuk menghilangkan berbagai polutan menggunakan prekursor yang terbarukan dan lebih murah yang terutama produk sampingan industri dan pertanian, seperti tempurung kelapa, ampas tebu, gula tebu serbuk kayu, jerami padi, bambu, serat kelapa sawit dan sabut kelapa.

Karbon aktif dapat dibuat dari material yang mengandung karbon. Salah satu material yang mengandung karbon adalah tempurung kelapa. Komposisi utama tempurung kelapa terdiri dari selulosa, lignin, hemiselulosa dengan kandungan atom-atom $\mathrm{C}, \mathrm{O}, \mathrm{H}$, dan $\mathrm{N}$. Menurut Hoque, karbon aktif dari tempurung kelapa, memiliki beberapa kelebihan daripada bahan lain, yaitu tingkat kekerasan yang tinggi sehingga mempermudah karakteristik penanganan nya, luas permukaannya di atas 
$1500 \mathrm{~m} 2$ /g, daya serapnya tinggi, abunya sedikit, dan kemurniannya tinggi.

Adsorpsi secara kontinyu mempunyai pendekatan yang jauh lebih baik untuk penerapan di lapangan karena sistem operasinya yang selalu mengontakkan adsorben dengan larutan segar, sehingga adsorben dapat mengadsorpsi dengan optimal sampai kondisi jenuhnya (Aksu, 2003 dalam Nurfitriyani dkk, 2012). Pada penelitian ini adsorben yang akan digunakan adalah karbon aktif dari tempurung kelapa.

Penelitian ini bertujuan untuk menganalisis efektifitas penurunan konsentrasi zat warna direk pada air limbah industri kain jumputan Palembang menggunakan karbon aktif yang terbuat dari tempurung kelapa dengan proses kontinyu. Karbon aktif yang dihasilkan akan diuji kualitasnya dan dibandingkan dengan arang aktif kualitas SNI. Selanjutnya membandingkan kinerja dari karbon aktif dengan berbagai variasi konsentrasi aktivator terhadap waktu adsorpsi untuk dilihat sejauh mana kinerja karbon aktif dapat menjernihkan air limbah jumputan sehingga dapat diketahui kemampuan penyerapannya.

\section{Zat Warna Tekstil}

Pewarna tekstil yang sering digunakan dalam industri dibedakan menjadi 2 yaitu pewarna alami dan pewarna sintetis. Zat warna sintetis (synthetic dyes) atau zat wana kimia adalah zat warna yang paling banyak digunakan dalam industri tekstil termasuk dalam pembuatan kain jumputan di Palembang, Sumatera Selatan. Selain mudah diperoleh, jenis zat warna sintetis ini lebih stabil dan praktis dalam pemakaiannya. Menurut Selvam dkk (2003), sekitar sebanyak 10.000 jenis pewarna digunakan oleh industry tekstil dan lebih dari 7 x 105 ton banyaknya bahan pewarna diproduksi setiap tahunnya.

Zat warna merupakan racun bagi tubuh manusia, meskipun ada zat warna tertentu yang aman bagi manusia yaitu zat warna untuk industri pangan dan farmasi. Pada proses pencelupan ada beberapa zat warna yang digunakan. Penggolongan secara terperinci biasanya didasarkan pada sifat-sifat dan penggunaannya yaitu zat warna asam, basa, direk, mordan, belerang, bejana, dispersi dan reaktif (Isminingsih, Djufri, dan Rasjid, 1982).

\section{Tempurung kelapa}

Tempurung kelapa merupakan struktur lapisan yang keras karena pada buah kelapa karena mengandung lignin sehingga membuatnya tahan terhadap benturan. Tempurung kelapa memiliki ketebalan 3mm sampai $5 \mathrm{~mm}$ yang diselimuti oleh serabut kelapa. Selain itu tempurung juga banyak mengandung silikat $\left(\mathrm{SiO}_{2}\right)$. Nilai kalor pada tempurung kelapa berkisar antara 18200 hingga 19388,05 kJ/kg (Palungkun, 1999).

Adapun Kandungan kimia yang terdapat di tempurung kelapa yang dapat dilihat pada Tabel 1 berikut:

Tabel 1. Komposisi Kimia Tempurung Kelapa

\begin{tabular}{cc}
\hline Komponen & $\begin{array}{c}\text { Persentase } \\
\text { (\%) }\end{array}$ \\
\hline Selulosa & 34 \\
Lignin & 27 \\
Hemiselulosa & 21 \\
Abu & 18 \\
\hline
\end{tabular}

\section{Sumber : Tamado, 2013}

Karbon aktif tempurung kelapa yang memiliki kemampuan daya adsorbsi tinggi mempunyai komponen penyusun kimiawi yang tercantum pada Tabel 2 berikut:

Tabel 2. komponen penyusun kimiawi karbonaktif tempurung kelapa

\begin{tabular}{cc}
\hline Komponen & Persentase (\%) \\
\hline C & 74,3 \\
O & 21,9 \\
Si & 0,2 \\
K & 1,4 \\
S & 0,5 \\
P & 1,7 \\
\hline
\end{tabular}

Sumber : Bledzki,A.K.,dkk (2010)

\section{Karbon Aktif}

Karbon aktif adalah bahan atau material yang mengandung karbon bebas memiliki banyak pori-pori yang sangat kecil sehingga memiliki daya serapan yang besar terhadap zat-zat disekitarnya baik dalam bentuk gas maupun cair. dimana semakin kecil pori-pori arang aktif, maka mengakibatkan luas permukaan semakin besar (Desiani, 2014).

Daya serap tinggi yang dimiliki oleh karbon aktif sehingga membuatnya dapat dengan mudah menyerap gas maupun residu didalam larutan. Karbon aktif adalah karbon amorf yang mempunyai luas permukaan berkisar 300 sampai $2000 \mathrm{~m}^{2} / \mathrm{gr}$ (Azhary dan Fuadi, 2008). Dikarenakan luas permukaannya yang besar maka kemampuannya untuk menyerap sangat besar. Daya serap karbon 
aktif sangat besar, yaitu 25 - $1000 \%$ terhadap berat karbon aktif, (Siti Salamah, 2008).

\section{METODE PENELITIAN}

Bahan baku yang digunakan berupa limbah cair zat warna direk kain jumputan buatan yang diadsorpsi dengan menggunakan karbon aktif dari limbah tempurung kelapa. Analisa yang digunakan untuk konsentrasi zat warna direk limbah jumputan menggunakan instrumen Spektrofotometri UV-VIS dan SEM.

\section{Prosedur Pembuatan Karbon Aktif Tempurung Kelapa}

\section{A. Persiapan Bahan Baku}

Limbah Tempurung kelapa yang berasal dari daerah Sukamoro, Banyuasin dicuci terlebih. Selanjutnya dikeringkan di bawah sinar matahari hingga kering. Limbah Tempurung kelapa yang sudah dikeringkan, kemudian dimasukkan kedalam karung untuk digunakan pada proses selanjutnya.

\section{B. Tahap Karbonisasi}

Tempurng kelapa dimasukkan kedalam furnace selama 2 jam dengan suhu $550{ }^{\circ} \mathrm{C}$. Setelah menjadi arang, tempurung kelapa digiling dengan disc pulverizer dan dihaluskan dengan alat HGI. Karbon yang telah halus diayak menggunakan ayakan dengan ukuran < 18 mesh lalu dimasukkan kedalam kantong plastik untuk digunakan pada proses selanjutnya.

\section{Tahap Aktivasi}

Karbon direndam dalam larutan $\mathrm{HCl}$ sebagai aktivator dengan variasi konsentrasi 0 , 5, 10, $15 \% \mathrm{w} / \mathrm{v}$ selama 24 jam dengan perbandingan massa arang : massa aktivator 1 : 3. Karbon yang telah direndam kemudian disaaring dengan kertas saring Whatman kemudian dicuci dengan aquadest hingga $\mathrm{pH}$ nya netral. Karbon dikeringkan dalam oven selama $\pm 1,5$ jam pada suhu $110{ }^{\circ} \mathrm{C}$. Lalu didinginkan dalam desikator selama \pm 20 menit untuk dan menghilangkan uap air yang menempel didalamnya. Karbon aktif siap dianalisa karakteristiknya.

\section{Analisa Awal Karakteristik Karbon Aktif}

Karbon aktif yang dihasilkan selanjutnya dianalisa karakteristiknya antara lain: rendemen, kadar air, kadar abu, kadar zat terbang, dan bilangan iod.

\section{A. Penentuan rendemen}

Bahan baku tempurung kelapa ditimbang sebanyak $6 \mathrm{~kg}$. Tempurung kelapa dikarbonisasi didalam furnace selama 2 jam dengan suhu $550 \quad{ }^{\circ} \mathrm{C}$. Karbon yang dihasilkan ditimbang untuk dihitung rendemen nya dengan menggunakan rumus: Rendeman $=\frac{\text { berat sampel setelah karbonisasi }}{\text { berat sampel awal }} \times 100 \%$

\section{B. Penentuan kadar air (SNI 06-3730-} 1995)

Krusibel dipanaskan dalam oven pada suhu $110{ }^{\circ} \mathrm{C}$ selama $1 / 2$ jam, kemudian didinginkan dalam desikator \pm 15 menit, dan ditimbang berat kosongnya. Karbon aktif ditimbang sebanyak 1 gr lalu dimasukkan ke dalam krusibel yang telah dikeringkan. Krusibel yang berisi karbon aktif dipanaskan kembali dalam oven selama 2 jam pada suhu $110^{\circ} \mathrm{C}$. Setelah 2 jam, krusibel dikeluarkan dari oven kemudian didinginkan ke dalam desikator selama \pm 30 menit, dan ditimbang beratnya. Kadar air dalam sampel karbon aktif dihitung dengan persamaan :

Dimana :

$$
\text { Kadar air }=\frac{m_{2}-m_{3}}{m_{2}-m_{1}} \times 100 \%
$$

$\mathrm{m}_{1}=$ Massa krusibel (gr)

$\mathrm{m}_{2}=$ Massa krusibel + sampel sebelum pemanasan (gr)

$\mathrm{m}_{3}=$ Massa krusibel + sampel setelah pemanasan (gr)

\section{Penentuan Kadar Abu (SNI 06-3730- 1995)}

Krusibel di oven pada suhu $110{ }^{\circ} \mathrm{C}$ selama $1 / 2$ jam, kemudian dinginkan dan ditimbang berat kosongnya. Karbon aktif sebanyak 1 gr dimasukkan ke dalam krusibel kemudian dimasukkan ke dalam furnace selama 2,5 jam pada suhu $600{ }^{\circ} \mathrm{C}$ hingga menjadi abu. Dinginkankan krusibel ke dalam desikator selama \pm 30 menit, dan ditimbang. Penentuan kadar abu dalam sampel karbon aktif dapat dihitung dengan persamaan :

Dimana :

$$
\text { Kadar abu }=\frac{m_{3}-m_{1}}{m_{2}-m_{1}} \times 100 \%
$$

$$
\begin{array}{ll}
\mathrm{m}_{1} & =\text { Massa krusibel }(\mathrm{gr}) \\
\mathrm{m}_{2} & =\text { Massa krusibel + sampel awal (gr) } \\
\mathrm{m}_{3} & =\text { Massa krusibel + abu (gr) }
\end{array}
$$

\section{Penentuan Kadar Zat Terbang (SNI 06- 3730-1995)}

Krusibel di oven pada suhu $110{ }^{\circ} \mathrm{C}$ selama $1 / 2$ jam, dinginkan dalam desikator \pm 15 menit, dan ditimbang berat kosongnya. Karbon aktif sebanyak 1 gr dimasukkan ke dalam krusibel kemudian dimasukkan ke dalam furnace selama 2,5 jam pada suhu $700{ }^{\circ} \mathrm{C}$ hingga menjadi abu. Krusibel didinginkan ke 
dalam desikator selama \pm 30 menit, dan ditimbang. Penentuan kadar zat terbang dalam sampel karbon aktif dapat dihitung dengan persamaan :

$$
\text { Kadar zat terbang }=\frac{\mathrm{m}_{2}-\mathrm{m}_{3}}{\mathrm{~m}_{2}-\mathrm{m}_{1}} \times 100 \%-\mathrm{M}_{\mathrm{ad}}
$$

Dimana :

$\mathrm{m}_{1}=$ Massa krusibel (gr)

$\mathrm{m}_{2}=$ Massa krusibel + sampel sebelum pemanasan (gr)

$\mathrm{m}_{3}=$ Massa krusibel + sampel setelah pemanasan (gr)

$\mathrm{M}_{\mathrm{ad}}=$ Kadar air (\%)

\section{E. Penentuan Bilangan Iod (SNI 06-3730- 1995)}

Untuk blanko, sebanyak $10 \mathrm{~mL}$ larutan iod 0,1 $\mathrm{N}$ dipipet dan dimasukkannya ke dalam erlenmeyer. Kemudian dititrasi dengan larutan natrium tiosulfat $0,1 \mathrm{~N}$ sampai warna kuning menjadi samar lalu ditambahkan $5 \mathrm{~mL}$ larutan kanji dan dititrasi kembali sampai warna biru menghilang.

Karbon aktif dipanaskan dalam oven selama 1 jam pada suhu $110{ }^{\circ} \mathrm{C}$ dan selanjutnya didinginkan. Sebanyak 0,125 gr karbon aktif dimasukkan ke dalam Erlenmeyer dan ditambahkan $25 \mathrm{~mL}$ larutan. Campuran tersebut dihomogenkan selama \pm 15 menit lalu disaring dengan kertas saring Whatman. Dipipet $10 \mathrm{~mL}$ filtrat dan dimasukkan ke dalam erlenmeyer. Diulangi langkah 1.

Penentuan bilangan iod menggunakan persamaan :

$$
\text { Bil iod }=\frac{25}{10} \times \frac{\left(V_{\text {blanko }}-V_{\text {sampel }}\right) \times \mathrm{N} \mathrm{Na}_{2} \mathrm{~S}_{2} \mathrm{O}_{3} \times \mathrm{BE} \mathrm{I}_{2}}{\mathrm{~m}_{\text {sampel }}}
$$

Dimana :

$$
\begin{array}{ll}
\mathrm{V}_{\text {blanko }} & =\text { Volume blanko }(\mathrm{mL}) \\
\mathrm{V}_{\text {sampel }} & =\text { Volume sampel }(\mathrm{mL}) \\
\mathrm{N} \mathrm{Na}_{2} \mathrm{~S}_{2} \mathrm{O}_{3} & =\text { Normalitas } \mathrm{Na}_{2} \mathrm{~S}_{2} \mathrm{O}_{3}(\mathrm{mek} / \mathrm{mL}) \\
\mathrm{BE} \mathrm{I}_{2} & =\text { Berat ekivalen } \mathrm{I}_{2}(\mathrm{mg} / \mathrm{mek}) \\
\mathrm{m}_{\text {sampel }} & =\text { massa karbon aktif }(\mathrm{gr})
\end{array}
$$

\section{Proses Pembuatan Limbah Zat Warna Direk Kain Jumputan}

Membuat larutan zat warna dengan melarutkan zat warna direk kuning, zat warna direk hijau tua dan asam cuka masing-masing perbandingan 1:1:1 kemudian dicampurkan dengan air sebanyak 5 liter didalam panci. Larutan dipanaskan hingga mendidih. larutan zat warna dimasukkan ke dalam dirijen 25 liter hingga penuh dan tercampur rata.

\section{Proses Adsorpsi Limbah Kain Jumputan dengan Karbon Aktif}

Membuat rangkaian alat adsorbsi skala laboratorium seperti pada Gambar 1.

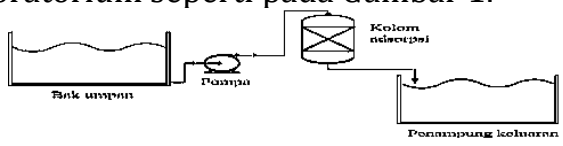

\section{Gambar 1. Rangkaian Alat Absorbsi}

Bak umpan diisi dengan air limbah kain jumputan dengan konsentrasi 112,132 ppm, pH 4,05, dan temperatur ruang. kolom adsorpsi diisi dengan karbon aktif dengan tinggi 9,8 inch dan berat karbon aktif 300 . Pompa dihidupkan dan kemudian air limbah kain jumputan dialirkan ke dalam kolom adsrobsi hingga terisi penuh. Mematikan pompa dan mengambil air keluaran dari alat.

\section{HASIL DAN PEMBAHASAN Kualitas Karbon Aktif}

Sebelum proses adsorpsi dimulai, perlu adanya pengujian terhadap kualitas karbon aktif terlebih dahulu. Parameter yang diuji untuk menentukan kualitas karbon aktif antara lain adalah kadar air, kadar abu, kadar zat terbang dan daya serap terhadap iodin. Pengujian ini dilakukan untuk melihat kualitas karbon aktif yang akan dijadikan adsorben pada penyerapan zat warna direk. Hasil karakterisasi kemudian dibandingkan dengan karakter karbon menurut SNI 06 - 3730 1995 tentang arang aktif teknis.

\section{a. Kadar air}

Kandungan air merupakan banyaknya air yang terkandung dalam karbon aktif setelah bahan baku berkarbon melalui tahapan karbonisasi dan aktivasi kimia, baik yang terikat secara kimiawi maupun akibat pengaruh kondisi luar seperti iklim, ukuran butiran maupun proses penyaringan. Penentuan kadar air bertujuan untuk mengetahui sifat higroskopis dari karbon aktif. Hasil karakterisasi kadar air ditampilkan pada Tabel 3.

Tabel 3. Kadar Air Karbon Aktif

\begin{tabular}{cc}
\hline HCL $(\%)$ & Kadar Air (\%) \\
\hline 0 & 4,15 \\
5 & 1,98 \\
10 & 1,44 \\
15 & 1,30 \\
\hline
\end{tabular}

Nilai kadar air yang dihasilkan pada penelitian ini berkisar antara 1,30 - 4,15\%. Perhitungan kadar air karbon aktif ini didasarkan pada bobot kering oven arang aktif. Nilai kadar air karbon aktif yang diperoleh 
telah memenuhi Standar Nasional Indonesia (SNI) arang aktif teknis. SNI menetapkan kadar air arang aktif teknis maksimal $15 \%$. Apabila dibandingkan dengan arang aktif komersial, arang aktif pada penelitian ini memiliki nilai kadar air yang rendah. Arang aktif komersial memiliki nilai kadar air sebesar 8.54\%.

Pada penelitian ini, nilai kadar air pada karbon aktif dengan perendaman asam klorida $15 \%$ memiliki nilai yang paling kecil yaitu 1,30\%. Menurut (Pari, 2004) bahan pengaktif yang bersifat higroskopis dapat menurunkan kadar air. Terikatnya molekul air oleh aktivator akan meningkatkan kemampuan adsorpsi dari arang aktif tempurung kelapa. Sifat higroskopis menyebabkan arang aktif pada kondisi dan kelembaban tertentu akan mencapai suatu keseimbangan kadar air, keseimbangan kadar air ini merupakan sebuah ukuran higroskopisitas (Tsoumis, 1991). Semakin higroskopis suatu bahan maka kemampuan bahan untuk menarik kandungan air udara akan semakin tinggi. Menurut Hendra (2007), kadar air yang tinggi disebabkan oleh sifat higroskopis arang aktif dan juga adanya molekul uap air yang terperangkap di dalam kisi-kisi heksagonal arang aktif terutama pada saat proses pendinginan. Karbon aktif bersifat higroskopis sehingga mudah menyerap uap air dari udara. Hal ini dikarenakan strukturnya terdiri dari 6 atom C, membentuk kisi heksagonal yang memungkinkan uap air terperangkap di dalamnya (Pari 1996).

\section{b. Kadar Zat Terbang}

Kadar zat terbang merupakan parameter untuk mengukur banyaknya zat yang menguap pada saat proses pemanasan. Parameter tersebut dapat mengukur tingkat adsorpsi arang aktif. Semakin tinggi kadar zat terbang pada arang aktif maka sifat menyerap larutan dan gas akan semakin rendah. Kadar zat terbang merupakan zat yang dapat menguap sebagai hasil dekomposisi senyawasenyawa yang masih terdapat di dalam arang selain air. Hasil karakterisasi kadar zat terbang ditampilkan pada Tabel 4.

Tabel 4. Kadar Zat Terbang Karbon Aktif

\begin{tabular}{cc}
\hline HCL $(\%)$ & $\begin{array}{c}\text { Kadar Zat Terbang } \\
(\%)\end{array}$ \\
\hline 0 & 8,47 \\
5 & 8,60 \\
10 & 9,72 \\
15 & 9,90 \\
\hline
\end{tabular}

Hasil penelitian menunjukan nilai kadar zat terbang arang aktif rata-rata berkisar antara 8,47 - 9,90\%. Nilai kadar zat terbang tersebut masih memenuhi SNI arang aktif teknis. SNI menetapkan kadar zat terbang arang aktif maksimal 25\%. Kadar zat terbang terendah adalah kadar zat terbang tanpa perendaman asam klorida dengan nilai ratarata sebesar $8.47 \%$. Kadar zat terbang tertinggi adalah kandungan zat terbang dengan konsentrasi perendaman asam klorida 15\%. Apabila dibandingkan dengan arang aktif komersial, kadar zat terbang arang aktif pada penelitian ini masih rendah. Nilai kadar zat terbang arang aktif komersial adalah $24.51 \%$.

Tingginya kadar zat terbang pada karbon aktif dapat disebabkan oleh terbentuknya gugus fungsi pada saat aktivasi menggunakan asam klorida. Peningkatan kadar zat terbang diperkirakan akibat putusnya ikatan atom-atom seperti oksigen, nitrogen dan hidrogen pada gugus-gugus yang terbentuk dan menguap akibat pemanasan yang diberikan (Sudirjo, 2006).

\section{c. Kadar Abu}

Abu merupakan hasil degradasi senyawa anorganik atau mineral oleh suhu tinggi. Arang aktif yang dibuat dari bahan alam tidak hanya mengandung senyawa karbon saja, namun juga mengandung beberapa mineral. Kadar abu tersebut akan menunjukkan kandungan mineral yang terkandung dalam arang aktif (Jankowska et al., 1991). Hasil karakterisasi kadar abu ditampilkan pada Tabel 5.

Tabel 5. Kadar Abu Karbon Aktif

\begin{tabular}{cc}
\hline HCL (\%) & Kadar Abu (\%) \\
\hline 0 & 4,86 \\
5 & 3,69 \\
10 & 3,05 \\
15 & 3,04 \\
\hline
\end{tabular}

Kadar abu merupakan persentase berat oksida-oksida mineral dalam karbon seperti silikon, sulfur, kalsium, dan komponen lain yang tertinggal pada saat pemanasan dalam jumlah kecil. Penetuan kadar abu bertujuan untuk menentukan kandungan oksida logam yang masih terdapat dalam karbon aktif tempurung kelapa setelah melalui proses aktivasi pada suhu $500{ }^{\circ} \mathrm{C}$. Tingginya kadar abu pada karbon aktif dapat mempengaruhi daya adsorpsi baik terhadap larutan maupun gas. Abu yang terbentuk disebabkan karena bahan memiliki unsur mineral seperti kalsium, kalium, natrium, dan magnesium. Kandungan 
tersebut menyebar dalam kisi karbon aktif sehingga menutupi pori arang aktif (Pari et al, 2001)

Pada penelitian ini kadar abu yang diperoleh berkisar antara 3,04-4,86\%. Nilai terendah kadar abu adalah pada perlakuan karbon yang direndam dengan asam klorida. Kadar abu berhubungan dengan kandungan mineral seperti logam pada karbon aktif. Kosting dan Conrad (1931) melaporkan bahwa asam klorida dapat menyebabkan korosi pada logam-logam. Berdasarkan hal tersebut, logam yang terkandung pada karbon akan mengalami korosi pada saat aktivasi menggunakan asam klorida sehingga menyebabkan kadar abu karbon aktif yang lebih rendah daripada arang yang tidak diaktivasi.

\section{d.Kadar Karbon Terikat}

Kadar karbon terikat merupakan komponen fraksi karbon (C) yang terdapat dalam bahan selain komponen air, abu, dan zat terbang. Semakin tinggi nilai kadar karbon terikat maka kemurnian bahan terhadap fraksi karbon semakin tinggi. Penentuan kadar karbon bertujuan untuk mengetahui kadar karbon murni yang terkandung pada karbon aktif yang dihasilkan. Fraksi karbon dalam karbon aktif adalah hasil dari proses pengarangan selain air, abu, dan zat volatil. Hasil karakterisasi kadar karbon terikat ditampilkan pada Tabel 6 .

Tabel 6. Kadar Karbon Terikat

\begin{tabular}{cc}
\hline HCL $(\%)$ & $\begin{array}{c}\text { Kadar Karbon Terikat } \\
(\%)\end{array}$ \\
\hline 0 & 82,48 \\
5 & 85,73 \\
10 & 85,79 \\
15 & 85,86 \\
\hline
\end{tabular}

Nilai kadar karbon terikat pada penelitian ini memiliki nilai $82.48-85.86 \%$. Nilai tersebut telah memenuhi SNI arang aktif teknis yang menetapkan nilai kadar karbon terikat minimal sebesar 65\%. Nilai kadar karbon terikat terendah terdapat pada perlakuan karbon aktif tanpa perendaman asam klorida. Jika dibandingkan dengan karbon aktif komersial, nilai kadar karbon terikat pada penelitian ini lebih tinggi. Nilai kadar karbon terikat pada karbon aktif komersial rata-rata sebesar $68.22 \%$.

Tinggi dan rendahnya kadar karbon terikat dipengaruhi oleh nilai kadar abu dan kadar zat terbang pada karbon aktif. Semakin tinggi nilai kadar abu dan kadar zat terbang maka nilai kadar karbon terikat akan semakin rendah. Selain dipengaruhi oleh kadar zat terbang dan kadar abu, kadar karbon terikat juga dipengaruhi oleh kandungan selulosa dan lignin yang dapat dikonversi menjadi atom karbon. Aktivator asam klorida dapat melarutkan mineral yang terikat dengan molekul karbon pada arang dan menggantinya dengan suatu gugus fungsi (Kosting dan Conrad, 1931; Sudirjo, 2006). Hal ini dapat dilihat dari kadar zat mudah menguap yang meningkat akibat penambahan gugus fungsi dan kadar abu yang menurun akibat larutnya mineral bersama asam klorida.

\section{e. Daya Serap Iodin}

Daya serap iod menjadi salah satu parameter utama yang digunakan untuk menentukan mutu karbon aktif. Daya serap iod merupakan salah satu parameter pengujian pada karbon aktif untuk mengetahui kemampuan karbon aktif dalam menyerap pengotor maupun zat warna dalam bentuk larutan. Hasil karakterisasi daya serap iodin ditampilkan pada Tabel 7.

Tabel 7. Daya Serap Iodin

\begin{tabular}{cc}
\hline HCL $(\%)$ & $\begin{array}{c}\text { Daya Serap Iodin } \\
(\mathrm{mg} / \mathrm{g})\end{array}$ \\
\hline 0 & 50,7640 \\
5 & 279,202 \\
10 & 303,8548 \\
15 & 379,5156 \\
\hline
\end{tabular}

Nilai daya serap iod pada penelitian ini adalah $50,7640-379,5156 \mathrm{mg} / \mathrm{g}$. Nilai daya serap iod terendah pada penelitian ini terdapat pada perlakuan tanpa perendaman asam klorida, sedangkan nilai tertinggi terdapat pada perlakuan dengan perendaman asam klorida $15 \%$. Nilai daya serap iod pada arang aktif komersial adalah sebesar $326.36 \mathrm{mg} / \mathrm{g}$. Daya adsorpsi karbon aktif terhadap iod memiliki korelasi dengan luas permukaan dari karbon aktif. Semakin tinggi nilai daya serap iod maka semakin luas pembentukan pori-pori pada arang aktif yang dapat menyerap iod. Daya serap iod menunjukkan kemampuan karbon aktif yang memiliki ukuran molekul yang lebih kecil dari $10 \AA$ atau memberikan indikasi jumlah pori yang berdiameter $10-15 \AA$ (Rachmawati, 2004). Apabila karbon aktif mempunyai kemampuan menyerap iodin yang tinggi berarti arang aktif memiliki struktur pori mikro dan mesopori yang banyak (Miranti, 2012 dalam Metta Sylviana dkk, 2015). Jumlah pori karbon aktif yang banyak menyebabkan tumbukan antara partikel iodin dan karbon aktif meningkat, yang berarti 
jumlah molekul iodin yang diserap oleh karbon aktif akan meningkat pula.

Peningkatan daya serap iodin dari arang yang diaktivasi dapat terjadi karena aktivasi menggunakan aktivator asam klorida dapat membersihkan pori-pori dan memperluas permukaan arang serta memberikan gugus aktif sehingga dapat memperbesar daya serap karbon tersebut (Sudrajat dan Pari, 2011; Sudirjo, 2006).

\section{Morfologi Karbon Aktif}

Scanning Electron Microscopy (SEM) merupakan sejenis mikroskop yang menggunakan elektron sebagai pengganti cahaya untuk melihat benda dengan resolusi tinggi. Analisis SEM bermanfaat untuk mengetahui mikrostruktur (termasuk porositas dan bentuk retakan) benda padat. Dengan pengujian ini dapat diketahui proses pembentukan pori sebagai akibat dari aktivasi. Pengujian arang menggunakan SEM bertujuan untuk mengetahui bentuk perubahan permukaan karbon aktif pada kondisi aktivasi optimum sebelum dan setelah adsorpsi. Morfologi permukaan karbon aktif dilakukan pada pembesar 2.500 kali. Hasil analisa SEM bisa dilihat pada Gambar 2 berikut.

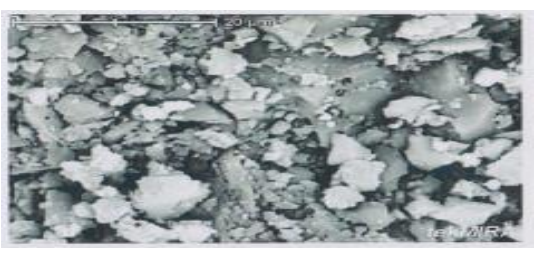

(a)

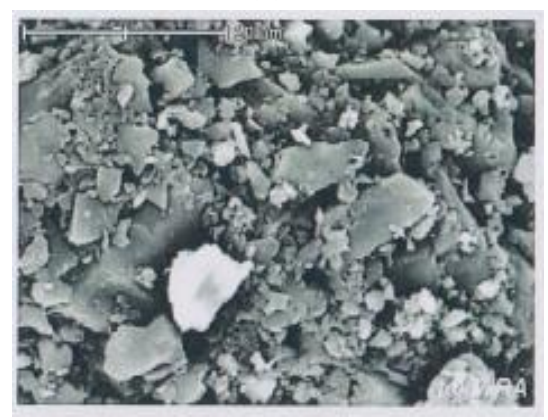

(b)

Gambar 2.

(a) Karbon aktif dengan aktivator $15 \%$ sebelum dilakukan adsorpsi

(b) Karbon aktif dengan aktivator $15 \%$ setelah dilakukan adsorpsi

Pada Gambar 2. tersebut terdapat perbedaan struktur karbon aktif tempurung kelapa sebelum dan sesudah dilakukan adsorpsi. Karbon aktif diberikan perlakuan dengan perendaman aktivator asam klorida $15 \%$ dengan waktu aktivasi selama 24 jam telah membentuk struktur pori yang lebih luas dan menyebar diseluruh permukaan karbon. Semakin banyak struktur pori pada permukaan arang aktif maka kemampuan dalam menyerap cairan dan gas akan semakin tinggi. Proses karbonisasi dan aktivasi mempengaruhi struktur pori-pori suatu bahan. Pori-pori terbentuk dari penguapan zat terbang serta terdegradasinya senyawa organik oleh panas. Menurut Novicio et al., (1998), terbentuknya pori karena adanya penguapan zat terbang yang terkandung di dalam bahan baku yang disebabkan oleh proses karbonisasi. Pori-pori yang terbentuk memiliki gaya van der waals yaitu gaya yang dapat menarik molekul sehingga terjadi peristiwa adsorpsi.

Gambar SEM dari karbon aktif sebelum dilakukan adsorpsi ditunjukkan pada Gambar 2. (a) Banyak pori-pori terlihat jelas di permukaan karbon. Karbon aktif tampaknya memiliki sejumlah besar pori-pori, dan kemungkinan besar bahwa pewarna akan terperangkap dan teradsorpsi ke dalam poripori ini. Makropori terlihat jelas, hal ini berguna untuk mempermudah difusi sejumlah besar molekul pewarna ke dalam struktur pori dan adsorpsi molekul pewarna ke permukaan adsorben. Morfologi material karbon hasil analisis menggunakan SEM/EDS terlihat terjadi pertumbuhan kristal yaitu teramati dengan bertambahnya ukuran partikel sebaran partikel karbon. Hasil analisis menunjukkan sebaran partikel yang tidak seragam dan bentuk partikel yang berbentuk tidak beraturan.

Perbedaan lain yang perlu diamati pada sampel karbon sebelum dan sesudah dilakukan adsorpsi adalah kandungan unsur yang terdapat pada karbon aktif tersebut. Analisis Energy Dispersive Spectroscopy (EDS) System JEOL JED-2200 merupakan analisis semi kuantitatif yang analisis jenis unsur material berdasarkan tingkat energi. Teknik SEM yang digabung dengan EDS dapat mengidentifikasi unsur-unsur yang dimiliki oleh fasa yang terlihat pada gambar struktur mikro. Hasil analisis EDS (Energy Dispersive Spectroscopy) spektrum yang menunjukkan komposisi unsur berdasarkan tingkat energi memperlihatkan unsur-unsur yang terdapat dalam karbon aktif sebelum dan sesudah adsorpsi. 


\section{Pengaruh Waktu Adsorpsi Terhadap Nilai Zat Warna Dengan Variasi Konsentrasi Aktivator}

Pewarna diperoleh dari pemasok lokal dan larutan disiapkan menggunakan air suling. Konsentrasi larutan pewarna ditentukan dengan mengukur absorbansi larutan pada panjang gelombang karakteristik $(\lambda \max .=$ 392nm) menggunakan spektrofotometer sinar UV-Vis berkas ganda (UV / VIS-1650 PC SHIMATZU). Hasil analisa konsentrasi zat warna asam dengan variasi konsentrasi adsorben dapat dijelaskan pada Tabel 8 . berikut ini.

Tabel 8. Pengaruh Waktu Adsorpsi Terhadap Nilai Zat Warna Dengan Variasi Konsentrasi Aktivator.

\begin{tabular}{cccccc}
\hline & Konse & \multicolumn{4}{c}{ Konsentrasi Sisa } \\
Konse & ntrasi & \multicolumn{4}{c}{ (Ce)(ppm) } \\
\cline { 3 - 6 } ntrasi & Awal & 10 & 20 & 30 & 40 \\
Aktivat & $(\mathrm{Co})(\mathrm{p}$ & men & men & men & men \\
or & pm) & it & it & it & it \\
\hline \multirow{2}{*}{0} & & 18,4 & 13,5 & 11,6 & 10,5 \\
& & 980 & 746 & 536 & 348 \\
& & 17,2 & 15,2 & 10,4 & 9,42 \\
$5 \%$ & 112,13 & 281 & 913 & 639 & 15 \\
& 2 & 15,8 & 13,0 & 9,27 & 9,91 \\
$10 \%$ & & 963 & 909 & 62 & 61 \\
& & 15,2 & 13,3 & 8,26 & 8,08 \\
$15 \%$ & & 652 & 725 & 59 & 65 \\
\hline
\end{tabular}

Dari Tabel 8. dapat dilihat bahwa adanya penurunan nilai konsentrasi zat warna setelah dilakukan adsorpsi. Gambar 3. menunjukkan pengaruh waktu adsorpsi terhadap nilai konsentrasi zat warna dengan variasi konsentrasi aktivator.

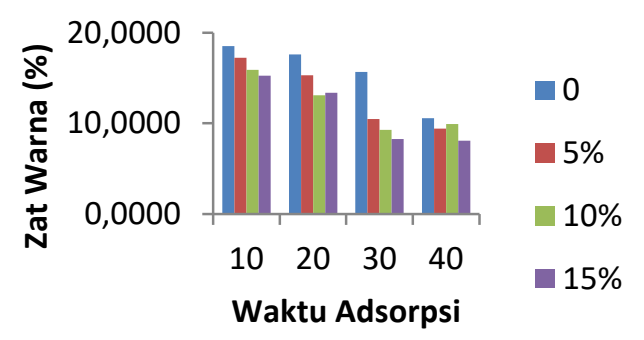

Gambar 3. Pengaruh Waktu Adsorpsi Terhadap Nilai Zat Warna Dengan Variasi Konsentrasi Aktivator.

Percobaan ini dilakukan untuk menentukan waktu kesetimbangan pada adsorpsi. Waktu adsorpsi dibuat bervariasi mulai dari 10 hingga 40 menit. Gambar 3. menjelaskan pengaruh waktu kontak. Semakin lama waktu kontak dapat memungkinkan proses difusi dan penempelan molekul adsorbat berlangsung lebih baik. Tingkat adsorpsi terjadi cepat pada tahap awal 10 menit pertama. Adsorpsi pewarna meningkat dengan meningkatnya waktu kontak dan semakin lama akan menjadi lambat sampai saturasi tercapai. Dapat dilihat pada Gambar 3. bahwa konsentrasi akhir zat warna direk selama 40 menit proses adsorpsi menunjukkan kenaikan. Ini menunjukkan bahwa waktu kesetimbangan terjadi pada 40 menit. Hal ini disebabkan oleh kejenuhan situs aktif yang tidak memungkinkan adsorpsi lebih lanjut terjadi. Meskipun demikian persentase adsorpsi terbesar terjadi pada waktu kontak 40 menit pada karbon aktif dengan variasi konsentrasi $15 \%$ dengan persentase adsorpsi sebesar $92,7 \%$. Hal ini sesuai dengan hasil uji karakteristik karbon aktif yang dilakukan sebelumnya bahwa kemampuan penyerapan karbon aktif dengan konsentrasi aktivator $15 \%$ memiliki daya serap yang lebih baik dari yang lainnya. Ini disebabkan karena aktivator membuat luas permukaan karbon aktif menjadi lebih besar sehingga menambah banyak pori pada karbon aktif. Luas permukaan adalah sifat paling penting dari adsorben karbon aktif untuk kapasitas adsorpsi. Secara umum, semakin besar luas permukaan maka semakin besar kapasitas adsorpsinya.

Tabel 9. Pengaruh Waktu Adsorpsi Terhadap Kapasitas Adsorpsi

\begin{tabular}{crrrr}
\hline $\begin{array}{c}\text { Konsent } \\
\text { rasi } \\
\text { aktivato }\end{array}$ & 10 & 20 & 30 & 40 \\
r & menit & menit & menit & menit \\
\hline $0 \%$ & 4,5393 & 4,5906 & 4,6099 & 4,6210 \\
& 94 & 39 & 43 & 16 \\
& 4,5528 & 4,5730 & 4,6217 & 4,6319 \\
$5 \%$ & 65 & 67 & 14 & 14 \\
& & 4,5955 & 4,6333 & 4,6270 \\
$10 \%$ & 4,5668 & 35 & 28 & 87 \\
& 4,5733 & 4,5926 & 4,6431 & 4,6448 \\
$15 \%$ & 37 & 88 & 03 & 28 \\
\hline
\end{tabular}

Untuk zat warna Direct dari grafik persen penurunan absorbansi terlihat bahwa penurunan terbesar terjadi pada waktu 40 menit. Waktu selama ini dibutuhkan karena alasan zat warna Direct mempunyai bobot molekul yang besar. Hal ini disebabkan struktur Direct cukup stabil dan mempunyai dua buah gugus azo, empat buah gugus sulfit dan enam gugus aromatik sehingga waktu yang diperlukan oleh karbon aktif lebih lama untuk menyerap ikatan-ikatan tak jenuh yang 
terdapat pada zat warna Direct. Dari Gambar 3. Persen penurunan absorbansi bebanding lurus dengan efesiensi penyerapan zat warna direk. Semakin kecil konsentrasi zat warna yang tertinggal setelah dilakukan adsorpsi maka semakin besar efisiensi penyerapan zat warna yang didapatkan.

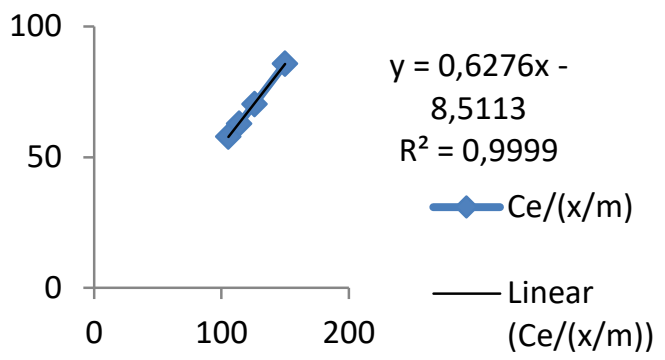

Gambar 4. Persamaan Adsorpsi Isoterm Langmuir dari $\mathrm{Ce} /(\mathrm{x} / \mathrm{m})$ versus $\mathrm{Ce}$

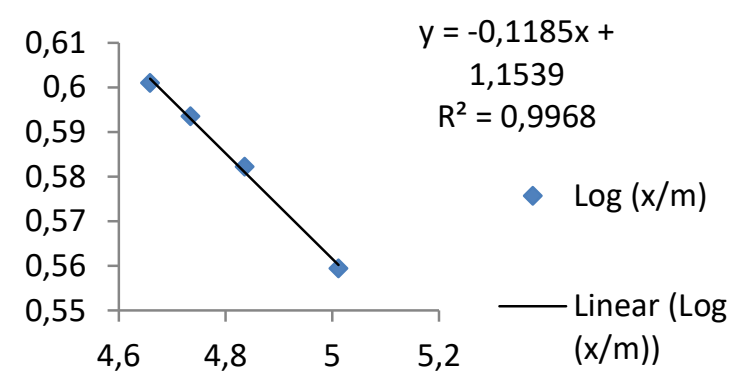

Gambar 5. Persamaan Adsorpsi Isoterm Fruendlich dari $\log (\mathrm{x} / \mathrm{m})$ versus $\log \mathrm{Ce}$

Pengujian pola isotherm adsorpsi yang sesuai untuk proses penyerapan zat warna Direct dilakukan dengan perhitungan menggunakan persamaan Langmuir dan Freundlich. Untuk menentukan persamaan isotherm Langmuir dan Fruendlich maka dihitung harga $x / m, C e /(x / m), \log C e /(x / m)$ dan log. Dari perhitungan yang didapat maka dilakukan pemetaan grafik menggunakan Excel dengan memplotkan harga $\mathrm{Ce} /(\mathrm{x} / \mathrm{m})$ versus $\mathrm{Ce}$ untuk mendapatkan persamaan Langmuir dan memplotkan $\log (\mathrm{x} / \mathrm{m})$ versus $\log \mathrm{Ce}$ untuk mendapatkan persamaan Freundlich. Hasil pemetaan dengan grafik seperti terlihat pada Gambar 4 dan 5.

Pengujian persamaan adsorpsi Langmuir dan juga persamaan adsorpsi Freundlich dibuktikan dengan grafik linierisasi yang baik dan mempunyai harga koefisien determinasi $\mathrm{R}^{2} \geq 0.9$ (mendekati angka 1). Dari Gambar 4 dan 5 terlihat bahwa persamaan adsorpsi zat warna Direct oleh karbon aktif memenuhi persamaan adsorpsi Langmuir juga persamaan adsorpsi Freundlich. Model persamaan Freundlich mengasumsikan bahwa terdapat lebih dari satu lapisan permukaan (multilayer) dan sisi bersifat heterogen, yaitu adanya perbedaan energi pengikat pada tiaptiap sisi dimana proses adsorpsi di tiap-tiap sisi adsorpsi mengikuti isoterm Langmuir. Oleh karena itu penentuan daya adsorpsi maksimum zeolit pada proses penyerapan zat warna Direct dihitung dengan menggunakan persamaan adsorpsi Langmuir karena dilakukan terhadap lapisan tunggal zat yang teradsorpsi dari zat warna pada setiap permukaan karbon aktif dalam satuan mg ion zat warna Direct yang teradsorp/gram karbon aktif.

\section{KESIMPULAN}

Dari hasil penelitian adsorpsi zat warna direk pada limbah cair jumputan menggunakan karbon yang dibuat dari tempurung kelapa sebagai adsorben diperoleh kesimpulan bahwa konsentrasi aktivator asam klorida mempengaruhi kualitas karbon aktif. Semakin tinggi konsentrasi asam klorida yang digunakan maka menghasilkan nilai kadar air, kadar abu, kadar zat terbang dan daya serap terhadap iodin yang sesuai dengan karakter karbon menurut SNI 06 - 3730 - 1995 tentang kualitas karbon aktif teknis. Adsorpsi pewarna meningkat dengan meningkatnya waktu kontak (10 - 40 menit) sehingga penurunan konsentrasi zat warna akan semakin besar. Hasil penelitian menunjukkan bahwa karbon aktif yang teraktivasi HCL 15\% (v/v) dengan waktu 40 menit memberikan hasil penyerapan terbaik yaitu sebesar 92,8\% dengan konsentrasi zat warna sisa sebesar 8,0865 $\mathrm{mg} / \mathrm{L}$.

\section{DAFTAR PUSTAKA}

Atmaji,P., P. Wahyu, P. P. Edi. 1999, Daur Ulang Limbah Hasil Pewarnaan Industri Tekstil, Jurnal Sains dan Teknologi Indonesia, Vol.1, No.4.

Badan Pusat Statistik. 2015. Jumlah Perusahaan Mikro dan Kecil di Indonesia Tahun 2010-2015. https://www.bps.go.id/linkTableDinam is/view/id/10 11

Brono, H. 2010. Mewarnai Batik Dengan Indigofera. Jakarta: Universitas Indonesia.

Chequer, D.M.F., Dorta., j.d., Oliveira, p.d. 2011. Azo Dyes and Their Metabolites: Does the Discharge of the Azo Dye into 
Water Bodies Represent Human and Ecological Risks?, Advances in Treating Textile Effluent, Prof. Peter Hauser (Ed.).

Chiou, M., Chuang, G., 2006. Competitive adsorption of dye metanil yellow and RB15 in acid solutions on chemically cross-linked chitosan beads. Chemosphere. 62, 731-740.

Fuadi Ramdja, Mirah Halim dan Jo Handi. 2008, Pembuatan Karbon Aktif dari Pelepah Kelapa (Cocus Nucifera), Jurnal Teknik Kimia, Vol.15, No. 2.

Dede Karyana. (2010). Pengantar Kimia Zat Warna. Bandung: Sekolah Tinggi Tekstil.

Demirbas, E., Kobya, M., Sulak, M.T., 2008. Adsorption kinetics of a basic dye from aqueous solutions onto apricot stone activated carbon. Bioresour. Technol. 99, 5368-5373.

Dewi, S.R, \& Lestari S. 2010.Dekolorisasi Limbah Batik Tulis Menggunakan Jamur Indigenous Hasil Isolasi Pada Konsentrasi Limbah Yang Berbeda. Jurnal Ilmiah Kimia Molekul, Vol. 5. No. 2. Nov, 2010 : $75-82$

Dilek, A. 2014. Production and Characterization of Activated Carbon from Sour Cherry Stones by Zinc Chloride. Fuel, 115: 804811.

Ghaedi, M., Sadeghian, B., Pebdani, A.A., Sahraei, R., Daneshfar, A., Duran, C., 2012. Kinetics, thermodynamics and equilibrium evaluation of direct yellow 12 removal by adsorption onto silver nanoparticles loaded activated carbon. Chem. Eng. J. 187, 133-141.

Ghaedi, M., Ansari, A., Sahraei, R., 2013. ZnS:Cu nanoparticles loaded on activated carbon as novel adsorbent for kinetic, thermodynamic and isotherm studies of reactive orange 12 and direct yellow 12 adsorption. Spectrochim Acta A Mol. Biomol. Spectrosc. 114, 687-694.

Gislon, P., S. Galli., G. Monteleone. 2013. Siloxanes Removal from Biogas by High Surface Area Adsorbents. Water Management, 33: 2687-2693.

Hadi, Rustan. 2011. Sosialisasi Teknik Pembuatan Arang Tempurung Kelapa dengan Pembakaran Sistem Suplai Udara Terkendali. Buletin Teknik Pertanian. Vol. 16, No. 2, 2011:hal. 7780.
Isminingsih, L. Djufri, Rasjid. 1982. Pengantar Kimia Zat Warna. Institut Teknologi Tekstil, Bandung.

Indonesia, Keputusan Gubernur Sumatera Selatan, 2002, Bahan Baku Mutu Limbah Cair Untuk Kegiatan Industri Tekstil, SK Gub. Sumsel No.13 tahun 2002.

Kismir, Y., Aroguz, A.Z., 2011. Adsorption characteristics of the hazardous dye brilliant green on Saklikent mud. Chem. Eng. J. 172, 199-206.

Liou, Tzong-Horng. 2010. Development of Mesoporous Structure and High Adsorpstion Capacity of Biomass-based Activated Carbon by Phosphoric Acid and Zinc Chloride Activation.Chemical Engineering Journal,158: 129-144.

Mahida, Azhary H. Surest, J. A. Fitri Kasih, dan Arfenny Wisanti. 1984. Pengaruh Suhu, Konsentrasi Zat Aktivator, dan Waktu Aktivasi Terhadap Daya Serap Karbon Aktif dari Tempurung Kemiri," Jurnal Teknik Kimia, No. 2

Mufidah, N. 2018. Pengaruh Laju Alir Pada Adsorpsi Zat Warna Remazol Yellow FG Menggunakan Kitosan Manik Dengan Sistem Kontinyu Kolom Tetap. Samarinda : Jurusan Teknik Kimia Program Studi Teknik Kimia Industri Politeknik Negeri Samarinda.

Palungkun, R. 1999. Aneka Produk Olahan Kelapa. Bogor : Penebar Swadaya.

Pari G. 1996. Pengolahan limbah melalui teknik pemanfaatan arang untuk membangun kesuburan lahan [artikel]. Bogor: Sekolah Pascasarjana, Institut Pertanian Bogor.

Pari G. 2002. Teknologi alternatif pemanfaatan limbah industri pengolahan kayu [artikel]. Bogor: Program Pascasarjana, Institut Pertanian Bogor.

Pari G. 2004. Kajian struktur arang aktif dari serbuk gergaji kayu sebagai adsorben emisi formaldehida kayu lapis [disertasi]. Bogor: Sekolah Pascasarjana, Institut Pertanian Bogor. 